\title{
Aile Sağlığı Merkezine Hizmet Almaya Gelen Gebelerin Psikososyal Sağlık Düzeyleri ve Etkileyen Faktörler
}

\author{
The Psychosocial Health Levels and its Affecting Factors of Pregnant Women Who \\ Obtained Care from the Family Health Centre
}

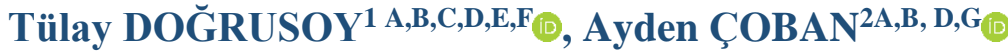 \\ ${ }^{1}$ Aydın İl Sağlık Müdürlüğü, Merkez 4 Nolu Aile Sağlığı Merkezi, Aydın, Türkiye \\ ${ }^{2}$ Aydın Adnan Menderes Üniversitesi Sağlık Bilimleri Fakültesi, Ebelik Bölümü, Aydın, Türkiye
}

ÖZ

\begin{abstract}
Amaç: $\mathrm{Bu}$ araştırma Aile Sağlığı Merkezine hizmet almaya gelen gebelerin psiko-sosyal sağlık düzeyleri ve etkileyen faktörlerin belirlenmesi amacıyla yapıldı.

Yöntem: Araştırma analitik-kesitsel tipte olup, 15 Mayıs 2016 -15 Kasım 2016 tarihleri arasında Aydın İli Merkez 4 Nolu Aile Sağlığı Merkezine hizmet almaya gelen 291 gebe ile yürütüldü. Araştırmanın verileri Anket Formu, Gebelikte Psikososyal Sağlığı Değerlendirme Ölçeği (GPSDÖ) ve Gebelikte Risk Değerlendirme Formu ile toplandı. Verilerin değerlendirilmesinde tanımlayıc istatistikler, Mann-Whitney U, Kruskal Wallis H ve Lojistik Regresyon Analizi kullanıldı.

Bulgular: Gebelerin GPSDÖ ölçeğine göre psikososyal sağlık durumlarının iyi düzeyde olduğu belirlendi. Gebelerin; yaş, eğitim, iş, gelir durumu, eşinin yaş ve eğitim durumu, gebelik sayısı, canlı doğum sayısı, gebeliğin planlanma ve gebeliğin istenme durumlarının psikososyal sağlığı etkilediği tespit edildi $(\mathrm{p}<0.05)$. Gebeliğin riskli olma durumları ile GPSDÖ puanı arasında anlamlı farklılık bulunmadı ( $>0.05$ ). Yapılan Lojistik Regresyon Analizi sonucunda gebeliğin istenmemesi toplam ölçek puanlarını düşürdüğü belirlendi.

Sonuç: Araştırmaya katılan gebelerin psikososyal sağlık düzeylerinin iyi olduğu tespit edildi. Bazı sosyo-ekonomik ve obstetrik özelliklerin psikososyal sağlık düzeylerini etkilerken, gebelikte risk durumunun etkilemediği belirlendi.
\end{abstract}

Anahtar Kelimeler: Gebelik, Psikososyal Sağlık, Ebelik

\section{ABSTRACT}

Objective: This study was carried out with the aim of determining the psychosocial health levels of pregnant women who obtained care from the family health centre and its affecting factors.

Methods: The study is analytical-cross-sectional and was conducted with 291 pregnant women who came to Aydın City Center No 4 Family Health Center between 15 May 2016 and 15 November 2016. The data of the study were collected using the Questionnaire Form, the Antenatal Psychosocial Health Assessment Tool, and the Risk Assessment Form in pregnancy. Descriptive statistics, Mann-Whitney U, Kruskal Wallis H and Logistic Regression Analysis were used to evaluate the data. Results: According to the scores from the Antenatal Psychosocial Health Assessment Tool,

the psychosocial health conditions of the pregnant women were at a good level. Age, education status, occupation, income status, spouse's age and education, number of pregnancies, number of live births, whether the pregnancy was planned and whether the pregnancy was wanted were found to affect psychosocial health $(p<0.05)$. No significant difference was found between the risk status of pregnancy and the Antenatal Psychosocial Health Assessment Tool scores ( $>0.05)$. As a result of the Logistic Regression Analysis; the pregnancy being unwanted reduced the total scale scores.

Conclusion: It was determined that the pregnant women participating in the study had good psychosocial health levels. It was determined that while some socio-economic and obstetric characteristics affected psychosocial health levels, risk status during pregnancy did not.

Sorumlu Yazar: Tülay DOĞRUSOY

Aydın İl Sağlık Müdürlüğü, Merkez 4 Nolu Aile Sağlığı Merkezi, Aydın, Türkiye

tulaydogrusoy@hotmail.com

Geliș Tarihi: 15 Şubat 2021- Kabul Tarihi: 3 Mayıs 2021

*Bu araştırmanın bir kısmı 26-28 Ekim 2018, 1.Uluslararası Tarım, Çevre ve Sağlık Kongresinde sözlü bildiri olarak sunulmuştur. Aynı zamanda bu araştırma Aydın Adnan Menderes Üniversitesi Sağlık Bilimleri Enstitüsü Ebelik Anabilim Dalı Yüksek Lisans Bitirme Tezinden oluşturulmuştur.

Yazar Katkıları: A) Fikir/Kavram, B) Tasarım, C) Veri Toplama ve/veya İşleme, D) Analiz ve/veya Yorum, E) Literatür Taraması, F) Makale Yazımı, G) Eleştirel İnceleme 
Key words: Pregnancy, Psychosocial Health, Midwifery.

\section{GİRIŞ}

Gebelik dönemi kadın için önemli psikososyal değişimlerin yaşandığı bir dönemdir (1). Gebeliğin normal seyrinde gitmesi için kadının fiziksel değerlendirmesi kadar psikososyal bakımdan değerlendirilmesi de önemlidir (2).

Gebelikte psikososyal sağlığın iyi düzeyde olması gebe, fetüs ve yenidoğan sağlı̆̆ için önemli bir durumdur. Gebelik kaygı ve stres oluşturabilecek birçok faktörle karşılaşma riskinin fazla olduğu bir dönemdir (3). Gebelik döneminde yaşanan depresyon ve stresin, gebelik, doğum ve doğum sonrası komplikasyonları arttırdığı, yenidoğan sağlığını olumsuz etkilediği belirlenmiştir. Preeklampsi, preterm eylem, distosi, doğumda cerrahi müdahale ihtiyacında artış, intrauterin gelişme geriliği, yenidoğanda düşük doğum ağırlığı ve düşük APGAR skoru depresyon ve stresin yol açtığı durumlar arasında yer almaktadır (1). Ülkemizde yapılan bir çalışmada gebelerin \%56.6'sının gebelikleri sürecince fiziksel, \%23.0'ının ise ruhsal rahatsızlık yaşadıkları bildirilmiştir (4). Gebelikte yaşanan ruhsal rahatsızlıkların gebelikle ilgili olumsuz sonuçlara yol açabileceği ve gerekli tedavi sağlanmazsa gebelerde maternal-fetal morbidite ve mortalite hızını arttırabileceği bilinmektedir (5).

Sağlık profesyonellerinin doğum öncesi dönemde gebelerin, hem fiziksel sağlık hem de psikososyal sağlıklarını değerlendirmeleri oldukça önemlidir. Bu değerlendirmenin yalnızca riskli gebelere değil tüm gebelere rutin olarak uygulanmasıyla tanı, tedavi ve sevk işlemleri vaktinde yapılabilecektir. Doğum öncesi bakım hizmetlerinde etkin role sahip olan ebeler, izlemde yalnızca gebenin fiziksel değerlendirmesinin yapıldı̆̆ değerlendirmeyi de kapsayan bütüncül bakım yaklaşım ile yapmalıdırlar. Ancak literatür incelendiğinde gebelerin psikososyal sağlık düzeyleri ve etkileyen faktörler ile ilgili bilgilerin sınırlı olduğu ve daha fazla bilimsel bilgiye gereksinim olduğu görülmüştür. Araştırmanın amacı gebelerin psikososyal sağlık düzeylerini değerlendirmek ve psikososyal sağlığı etkileyen faktörleri belirlemektir.

\section{GEREÇ VE YÖNTEMLER}

$\mathrm{Bu}$ araştırma analitik-kesitsel tipte bir araştırma olarak yapılmıştır. Araştırmanın evrenini Aydın İli Merkez 4 Nolu Aile Sağlığı Merkezine 15 Mayıs 2016 ile 15 Kasım 2016 tarihleri arasında kayıtlı 291 gebe oluşturmaktadır. Araştırmada örnekleme belirleme yöntemine başvurulmamış, evren örneklem olarak alınmıştır. Araştırmaya 15 Mayıs 2016-15 Kasım 2016 tarihleri arasında Aydın İli Merkez 4 Nolu Aile Sağlığı Merkezinde izlenen, 20 yaş üstü, ilkokul ve daha fazla eğitimi olan, Türkçe konuşup anlayabilen ve ruhsal rahatsızlığ olmayan 291 gebe dahil edilmiştir.

\section{Veri Toplama Araçları}

Araştırma verileri Anket Formu (3,9,11,17), Gebelikte Psikososyal Sağlı̆̆ Değerlendirme Ölçeği (7) ve Gebelikte Risk Değerlendirme Formu (8) kullanılarak toplanmiştır. 


\section{Anket Formu}

Form araştırmacılar tarafından literatüre dayalı olarak $(3,9,11,17)$ hazırlanmıştır. $\mathrm{Bu}$ formda gebeler ve eşlerinin tanıtıcı sosyo-demografik özelliklerini içeren 10 soru (yaş, eğitim, meslek, ekonomik durum, medeni durum, sosyal güvence), gebenin obstetrik özellikleri ve gebeliğe ilişkin bilgilerini kapsayan 16 soru (toplam gebelik sayısı, canlı doğum sayısı, düşük/kürtaj sayısı, yasayan çocuk sayısı, ölü doğum sayısı, gebelik haftası, gebeliğin planlanma durumu, gebelik takibi, gebelikten önce yaşanılan sağlık sorunu, gebelikte bedensel şikayet) olmak üzere toplam 26 soru yer almaktadır.

\section{Gebelikte Psikososyal Sağlığı Değerlendirme Ölçeği (GPSDÖ)}

Gebelikte psikososyal sağlığı değerlendirmek amacıyla Yıldız (2011) tarafından geliştirilmiştir. Ölçek 46 maddeden ve altı alt boyuttan oluşmakta olup, beşli likert türündedir. Ölçekteki birinci alt boyutta yer alan 13 madde 'Gebelik ve eş ilişkisine ait özellikler', ikinci alt boyutta yer alan sekiz madde 'Kaygı ve strese ait özellikler', üçüncü alt boyutta yer alan yedi madde 'Aile içi şiddete ait özellikler', dördüncü alt boyutta yer alan yedi madde 'Psikososyal destek gereksinimine ait özellikler', beşinci alt boyutta yer alan dört madde 'Ailesel özellikler' ve altıncı alt boyutta yer alan altı madde de 'Gebeliğe ilişkin fiziksel-psikososyal değişikliklere ait özellikler’ kapsamındadır (7).

Ölçeğin değerlendirilmesinde elde edilen toplam puan madde sayısına bölünerek madde puan ortalaması saptanır ve bir ile beş arasında sonuç elde edilmektedir. Ölçekten elde edilebilecek minimum değer bir ve maksimum değer beşdir. Sonuçta toplam ve alt boyut puanı beşden uzaklaşıp bire yaklaştıkça gebelikte psikososyal sağlıkta veya ilgili alt boyuta ait problem olduğunu gösterir. Ölçeğin kesme noktası bulunmamakta olup güvenirlik çalışmasında Cronbach's Alfa iç tutarlılık değeri 0.93 olarak belirtilmiştir. Bu çalışmada toplam ölçeğin Cronbach's Alfa iç tutarlılık değeri 0.88 olarak belirlenmiştir.

\section{Gebelikte Risk Değerlendirme Formu}

Yüksek riskli gebeleri saptamak için T.C. Sağlık Bakanlığı tarafından önerilen Risk Değerlendirme Formu kullanılmıştır. Bu formda kadınların tıbbi öykü, obstetrik öykü ve mevcut gebeliğin değerlendirmesi ile ilgili riskli durumların sorgulandığı 69 soru yer almaktadır. Formdaki her soru 'Evet' ve 'Hayır' şeklinde cevaplanmaktadır. Forma göre, sorulardan herhangi birine evet cevabı verilirse, gebenin riskli/yüksek riskli olduğu kabul edilmekte ve mutlaka kadın doğum uzmanı bulunan bir sağlık kuruluşuna sevk edilmesi gerekmektedir (8).

\section{Verilerin Toplanması}

Araştırmaya katılmayı kabul eden gebelerin yazılı onamı alındıktan sonra araştırmanın Anket formu ve Gebelikte Risk Değerlendirme formu araştırmacı tarafından yüz yüze görüşme tekniği kullanılarak, Gebelikte Psikososyal Sağlığı Değerlendirme Ölçeği ise gebeler tarafından doldurulmuştur. 


\section{Verilerin Değerlendirilmesi}

Verilerin istatistiksel analizinde Statistical Package for the Social Sciences (SPSS) 18.0 programı kullanılmıştır. Kolmogorov-Smirnov Z test sonuçlarına göre verilerin normal dağılım özelliği göstermediği belirlenmiş ve parametrik olmayan testler kullanılmıştır. İki grup değişkenleri arasındaki farklılığı incelemek için Mann-Whitney U testi ve birden fazla grup değişkenlerini incelemek için Kruskal Wallis H testi kullanılmıştır. GPSDÖ ve alt boyutlarının gebelerin psikososyal sağlık düzeyini ne ölçüde etkilediğini belirlemek amacıyla Lojistik Regresyon Analiz testi yapılmıştır. GPSDÖ, "Gebelik ve eş ilişkisine ait özellikler”, "Aile içi şiddete ait özellikler” ve "Gebeliğe ilişkin fiziksel-psikososyal değişikliklere ait özellikler" alt boyutlarının paralellik varsayımı sağladığı görülmüştür. Paralellik varsayımı sağlanmayan alt boyutlar için regresyon modelinin yorumlaması yapılmamıştır.

\section{Araştırmanın Etik Yönü}

Araştırma için 12.05.2016 tarihinde Adnan Menderes Üniversitesi Tıp Fakültesi Girişimsel Olmayan Klinik Araştırmalar Etik Kurulundan (Protokol no:2016/862) ve Aydın Halk Sağlık Müdürlüğü'nden yazılı izin alınmıştır. Araştırmaya katılan gebelere araştırma hakkında bilgi verildikten sonra sözlü ve yazılı onamları alınmıştır.

\section{BULGULAR}

Çalışmaya katılan gebelerin yaş ortalaması $27.68 \pm 4.82$ olarak bulunmuştur. Gebelerin \%37.1'inin üniversite mezunu, \%29.9'unun gelir getiren bir işte çalıştığı ve çalışan gebelerin \%70.4'ünün serbest meslek olarak çalıştığı belirlenmiştir. Araştırmaya katılan gebelerin \%99.0'ının resmi nikahlı, \%85.9'unun çekirdek aile, \%89.3'ünün orta gelirli ve \%96.6'sının sosyal güvencesinin var olduğu saptanmıştır. Gebelerin eşlerinin yaş ortalamasının $31.31 \pm 5.51$ olduğu, eşlerin \%30.2'sinin üniversite mezunu, \%97.9'unun gelir getiren bir işte çalıştığı ve bunlardan \% 77.2'sinin işçi olarak çalıştı̆̆ tespit edilmiştir. Gebelerin gebelik sayısı ortalaması $1.99 \pm 1.05$ olarak bulunmuştur. Gebelerin \%41.6'sının ilk gebeliği olduğu ve gebelik haftası ortalamasının $22.75 \pm 8.83$ olduğu bulunmuştur. Gebelerin \%48.5'inin canlı doğum yapmadığ \%82.8'inin düşük yapmadığı, \%95.9'unun kürtaj olmadığ̀, \%49.1'inin çocuğunun olmadığg, \%2.4'ünün bir ölü doğum yaptığı ve bir önceki doğumdan sonra geçen süre ortalamasının $44.91 \pm 34.11$ ay olduğu tespit edilmiştir.

Çalışmaya katılan gebelerin \%74.2'sinin mevcut gebeliğinin planlı olduğu ve \%82.8'inin isteyerek gebe kaldı ğ tespit edilmiştir. Gebelerin \%92.8'inin doğum öncesi bakım hizmeti aldığı ve \%97.6'sının her çağırıldığında sağlık kurumuna gittiği tespit edilmiştir. Çalışmamızda gebelerin \%87.6'sının sağlık sorununun olmadığı ve sağlık sorunu olanların \%19.6'sının bedensel şikayetinin olduğu belirlenmiştir.

Araştırmaya katılan gebelerin GPSDÖ toplam puan ortalaması $4.18 \pm 0.4$ idi. Ölçeğin alt boyutlarından olan "gebelik ve eş ilişkisine ait özellikler" puan ortalamasının $4.38 \pm 0.52$;

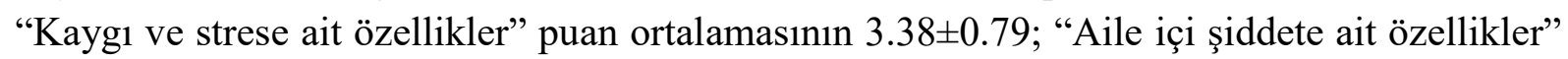
puan ortalamasının 4.80 \pm 0.32 ; "Psikososyal destek gereksinimine ait özellikler" puan ortalamasının $4.03 \pm 0.61$; “Ailesel özellikler" puan ortalamasının $4.40 \pm 0.63$ ve "Gebeliğe ilişkin fiziksel-psikososyal değişikliklere ait özellikler" puan ortalamasının $4.07 \pm 0.63$ olduğu belirlenmiştir (Tablo 1). 
Araştırmaya katılan gebelerin obstetrik ve mevcut özellikleri ile GPSDÖ ve alt boyutlarından aldıkları puanların karşılaştırılması Tablo 2'de verilmiştir. Araştırmaya katılan gebelerin gebeliğin planlanma ve gebeliğin istenme durumu ile GPSDÖ toplam puan ortalamaları arasında istatistiksel olarak anlamlı fark olduğu belirlenmiştir $(\mathrm{p}<0.05)$.

Tablo 1. GPSDÖ ve Alt Boyutlarına Yönelik Aldıkları Puanların Dağılımı

\begin{tabular}{lllll}
\hline \multicolumn{1}{c}{ Toplam ve Alt Boyutlar } & N & Min. & Max. & Ort. \pm SS \\
\hline GPSDÖ & 291 & 2.57 & 4.91 & $4.18 \pm 0.40$ \\
\hline Gebelik ve eş ilişkisine ait özellikler & 291 & 2.54 & 5.00 & $4.38 \pm 0.52$ \\
\hline Kaygi ve strese ait özellikler & 291 & 1.00 & 5.00 & $3.38 \pm 0.79$ \\
\hline Aile içi şiddete ait özellikler & 291 & 2.25 & 5.00 & $4.80 \pm 0.32$ \\
\hline $\begin{array}{l}\text { Psikososyal destek gereksinimine ait } \\
\text { özellikler }\end{array}$ & 291 & 2.14 & 5.00 & $4.03 \pm 0.61$ \\
\hline Ailesel özellikler & 291 & 2.50 & 5.00 & $4.40 \pm 0.63$ \\
\hline $\begin{array}{l}\text { Gebeliğe ilişkin fiziksel-psikososyal } \\
\text { değişikliklere ait özellikler }\end{array}$ & 291 & 1.00 & 5.00 & $4.07 \pm 0.63$ \\
\hline
\end{tabular}

Araştırmaya katılan gebelerin gebelikte risk, tıbbi öyküde risk ve obstetrik öyküde risk durumu ile GPSDÖ toplam puan ortalamaları arasında istatistiksel olarak anlamlı fark bulunmamıştır ( $>0.05$ ). Gebelikte risk durumu ile "Gebelik ve eş ilişkisine ait özellikler" ve "Kaygı ve strese ait özellikler" alt boyut puan ortalamaları arasında istatistiksel olarak anlamlı fark bulunmuştur $(\mathrm{p}<0.05)$. Gebelerin mevcut gebelik risk durumu ile "Kaygı ve strese ait özellikler” ve "Gebeliğe ilişkin fiziksel-psikososyal değişikliklere ait özellikler" alt boyut puan ortalamaları arasında istatistiksel olarak anlamlı fark olduğu belirlenmiştir $(p<0.05)$ (Tablo 3 ).

Tablo 4'te gebelerin GPSDÖ ve alt boyutları Lojistik Regresyon Analiz sonuçları verilmiştir. Yapılan Lojistik Regresyon Analiz sonucuna göre gebelerin GPSDÖ ile gebeliğin istenme durumu (hayır) arasında istatistiksel olarak anlamlı farklılık bulunmuştur $(\mathrm{p}<0.05)$. GPSDÖ alt boyutları olan "Gebelik ve eş ilişkilerine ait özellikleri” ile gelir durumu (düşük), "Gebelerin aile içi şiddete ait özellikleri” ile eğitim durumu (ilkokul, ortaokul), çekirdek aile, gebelik takibi (hayır), "Gebeliğe ilişkin fiziksel-psikososyal değişikliklere ait özellikleri” ile kürtaj sayısı (yok) arasında istatistiksel olarak anlamlı fark olduğu bulunmuştur $(\mathrm{p}<0.05)$.

\section{TARTIŞMA}

Bu araştırma Aydın İli Merkez 4 Nolu Aile Sağlığı Merkezine izlem için gelen gebelerin psikososyal sağlık düzeyleri ve etkileyen faktörlerin belirlenmesi amacıyla analitik-kesitsel tipte, 291 gebe ile yürütülmüştür. Bu bölümde araştırmadan elde edilen başlıca bulgular mevcut literatüre göre tartışılmıştır.

Gebelik döneminde psikososyal sağlığın olumsuz etkilenmesi gebe, fetüs ve yenidoğan sağlığını dolayısı ile aile ve toplum sağlığını olumsuz etkilemektedir (9). Çalışmamızda gebelerin genel olarak psikososyal sağlık durumlarının iyi düzeyde olduğu belirlenmiştir. Benzer olarak Gümüşdaş ve ark. (2014) yaptıkları çalışmada riskli olan gebelerin GPDSÖ toplam puanı $4.31 \pm 0.45$, risksiz gebelerin $4.14 \pm 0.41$ olduğu tespit edilmiş ve psikososyal sağlık düzeylerinin iyi olduğu saptanmıştır (9). Çalışmamızda, araştırmanın yapıldığı bölgede aile bağlarının iyi olması, gebeliğe olumlu bakılması ve gebelerin kendilerine her konuda yardımcı olabilecek kişilerin varlığından emin olması gebelerin psikososyal sağlık düzeyinin iyi olmasında etkili olabilir. 
Adnan Menderes Üniversitesi Sağlık Bilimleri Fakültesi Dergisi 2021: 5(3); 501-513

Journal of Adnan Menderes University Health Sciences Faculty

Tablo 2. Gebelerin Obstetrik ve Mevcut Özelliklerine Göre GPDSÖ Toplam ve Alt Boyutlarından Aldıkları Puanların Karşılaştırılması

\begin{tabular}{|c|c|c|c|c|c|c|c|}
\hline $\begin{array}{c}\text { Obstetrik ve } \\
\text { Mevcut } \\
\text { Özellikler }\end{array}$ & $\begin{array}{c}\text { Gebelik ve eş ilişkisine ait } \\
\text { özellikler }\end{array}$ & $\begin{array}{l}\text { Kaygı ve strese } \\
\text { ait özellikler }\end{array}$ & $\begin{array}{l}\text { Aile içi } \\
\text { şiddete ait } \\
\text { özellikler }\end{array}$ & $\begin{array}{l}\text { Psikososyal destek } \\
\text { gereksinimine ait } \\
\text { özellikler }\end{array}$ & Ailesel özellikler & $\begin{array}{c}\text { Gebeliğe ilişkin } \\
\text { fiziksel- } \\
\text { psikososyal } \\
\text { değişikliklere } \\
\text { ait özellikler } \\
\end{array}$ & GPSDÖ \\
\hline & Ort. \pm SS. & Ort. \pm SS & Ort. \pm SS & Ort. \pm SS & Ort. \pm SS & Ort. \pm SS & Ort. \pm SS \\
\hline \multicolumn{8}{|l|}{ Gebelik sayısı } \\
\hline $\begin{array}{l}\text { ilk gebelik } \\
(\mathrm{n}: 121)\end{array}$ & $4.57 \pm 0.41$ & $3.17 \pm 0.80$ & $4.79 \pm 0.38$ & $4.13 \pm 0.54$ & $4.48 \pm 0.59$ & $4.04 \pm 0.64$ & $4.22 \pm 0.37$ \\
\hline $\begin{array}{l}\text { 1'den fazla } \\
\text { (n:170) }\end{array}$ & $4.26 \pm 0.56$ & $3.53 \pm 0.75$ & $4.81 \pm 0.27$ & $3.96 \pm 0.64$ & $4.34 \pm 0.65$ & $4.09 \pm 0.62$ & $4.16 \pm 0.41$ \\
\hline Mann-Whitney U & 6904.000 & 7613.000 & 10261.000 & 8865.500 & 9115.000 & 9696.000 & 9549.000 \\
\hline p. & .000 & .000 & .971 & .044 & .092 & .403 & .298 \\
\hline \multicolumn{8}{|l|}{ Canlı doğum sayısı } \\
\hline İlk gebelik (n:141) & $4.57 \pm 0.44$ & $3.20 \pm 0.81$ & $4.80 \pm 0.36$ & $4.14 \pm 0.57$ & $4.50 \pm 0.58$ & $4.07 \pm 0.60$ & $4.23 \pm 0.37$ \\
\hline 1'den fazla (n:150) & $4.21 \pm 0.56$ & $3.54 \pm 0.74$ & $4.80 \pm 0.28$ & $3.93 \pm 0.63$ & $4.31 \pm 0.66$ & $4.07 \pm 0.65$ & $4.14 \pm 0.42$ \\
\hline Mann-Whitney U & 6504.000 & 8109.000 & 10433.000 & 8511.500 & 8818.500 & 10467.500 & 9271.500 \\
\hline p. & .000 & .001 & .833 & .004 & .013 & .880 & .069 \\
\hline \multicolumn{8}{|c|}{$\begin{array}{l}\text { Gebeliğin planlı olma } \\
\text { durumu }\end{array}$} \\
\hline Hayır (n:75) & $4.02 \pm 0.59$ & $3.37 \pm 0.89$ & $4.67 \pm 0.47$ & $3.75 \pm 0.66$ & $4.25 \pm 0.64$ & $3.96 \pm 0.77$ & $3.99 \pm 0.43$ \\
\hline Evet (n:216) & $4.51 \pm 0.43$ & $3.38 \pm 0.78$ & $4.85 \pm 0.23$ & $4.12 \pm 0.56$ & $445 \pm 0.62$ & $4.11 \pm 0.56$ & $4.25 \pm 0.36$ \\
\hline Mann-Whitney U & 4000.500 & 8087.500 & 5531.000 & 5444.000 & 6403.500 & 7437.500 & 5128.500 \\
\hline p. & .000 & .984 & .000 & .000 & .006 & .289 & .000 \\
\hline \multicolumn{8}{|c|}{ Gebeliğin istenme durumu } \\
\hline Hayır (n:50) & $3.85 \pm 0.60$ & $3.41 \pm 0.85$ & $4.65 \pm 0.43$ & $3.61 \pm 0.69$ & $4.18 \pm 0.68$ & $3.87 \pm 0.75$ & $3.91 \pm 0.43$ \\
\hline Evet $(\mathrm{n}: 241)$ & $4.50 \pm 0.42$ & $3.37 \pm 0.78$ & $4.83 \pm 0.28$ & $4.12 \pm 0,55$ & $4.45 \pm 0.61$ & $4.11 \pm 0.59$ & $4.24 \pm 0.37$ \\
\hline Mann-Whitney U & 2235.500 & 5837.000 & 4024.000 & 3427.500 & 4586.000 & 5014.000 & 3190.000 \\
\hline p. & .000 & .728 & .000 & .000 & .007 & .061 & .000 \\
\hline
\end{tabular}


Tablo 3. Gebelerin Risk Durumuna Göre GPSDÖ Toplam ve Alt Boyutlarından Aldıkları Puanların Karşılaştırılması

\begin{tabular}{|c|c|c|c|c|c|c|c|}
\hline Risk Durumu & $\begin{array}{l}\text { Gebelik ve eş } \\
\text { ilişkisine ait } \\
\text { özellikler }\end{array}$ & $\begin{array}{l}\text { Kaygı ve strese } \\
\text { ait özellikler }\end{array}$ & $\begin{array}{l}\text { Aile içi şiddete } \\
\text { ait özellikler }\end{array}$ & $\begin{array}{l}\text { Psikososyal } \\
\text { destek } \\
\text { gereksinimine } \\
\text { ait özellikler }\end{array}$ & Ailesel özellikler & $\begin{array}{l}\text { Gebeliğe ilişkin } \\
\text { fiziksel- } \\
\text { psikososyal } \\
\text { değişikliklere ait } \\
\text { özellikler }\end{array}$ & GPSDÖ \\
\hline Gebelikte risk durumu & Ort. \pm SS & Ort. \pm SS & Ort. \pm SS & Ort. \pm SS & Ort. \pm SS & Ort. \pm SS & Ort. \pm SS \\
\hline Risk yok (n:177) & $4.44 \pm 0.48$ & $3.29 \pm 0.82$ & $4.80 \pm 0.33$ & $4.07 \pm 0.60$ & $4.38 \pm 0.65$ & $4.04 \pm 0.62$ & $4.19 \pm 0.39$ \\
\hline Risk var (n:114) & $4.29 \pm 0.57$ & $3.51 \pm 0.73$ & $4.81 \pm 0.30$ & $3.96 \pm 0.62$ & $4.43 \pm 0.60$ & $4.11 \pm 0.63$ & $4.18 \pm 0.41$ \\
\hline Mann-Whitney U & 8448.500 & 8584.500 & 9926.500 & 9118.500 & 9953.500 & 9419.000 & 10026.500 \\
\hline p. & .019 & .032 & .805 & .165 & .844 & .337 & .929 \\
\hline \multicolumn{8}{|l|}{ Tıbbi öykü de risk } \\
\hline Risk yok (n:231) & $4.40 \pm 0.50$ & $3.35 \pm 0.81$ & $4.81 \pm 0.30$ & $4.06 \pm 0.59$ & $4.40 \pm 0.63$ & $4.05 \pm 0.65$ & $4.19 \pm 0.38$ \\
\hline Risk var (n:60) & $4.31 \pm 0.59$ & $3.49 \pm 0.72$ & $4.77 \pm 0.37$ & $3.92 \pm 0.65$ & $4.38 \pm 0.65$ & $4.13 \pm 0.53$ & $4.17 \pm 0.45$ \\
\hline Mann-Whitney U & 6298.500 & 6157.000 & 6468.000 & 6195.500 & 6778.500 & 6548.500 & 6855.000 \\
\hline p. & .276 & .183 & .397 & .205 & .790 & .509 & .897 \\
\hline \multicolumn{8}{|l|}{ Obstetrik öykü de risk } \\
\hline Risk yok (n:259) & $4.40 \pm 0.51$ & $3.35 \pm 0.80$ & $4.80 \pm 0.33$ & $4.02 \pm 0.61$ & $4.38 \pm 0.63$ & $4.06 \pm 0.63$ & $4.18 \pm 0.40$ \\
\hline Risk var (n:32) & $4.30 \pm 0.58$ & $3.57 \pm 0.76$ & $4.84 \pm 0.24$ & $4.09 \pm 0.62$ & $4.55 \pm 0.61$ & $4.17 \pm 0.55$ & $4.24 \pm 0.38$ \\
\hline Mann-Whitney U & 3721,000 & 3555.000 & 3841.500 & 3813.500 & 3309.000 & 3779.000 & 3794.000 \\
\hline p. & .345 & .189 & .473 & .460 & .058 & .414 & .436 \\
\hline \multicolumn{8}{|l|}{ Mevcut gebelik risk } \\
\hline Risk yok (n:222) & $4.40 \pm 0.52$ & $3.32 \pm 0.81$ & $4.78 \pm 0.35$ & $4.05 \pm 0.61$ & $4.39 \pm 0.65$ & $4.03 \pm 0.61$ & $4.17 \pm 0.40$ \\
\hline Risk var (n:69) & $4.32 \pm 0.52$ & $3.57 \pm 0.72$ & $4.88 \pm 0.18$ & $3.97 \pm 0.60$ & $4.43 \pm 0.58$ & $4.19 \pm 0.66$ & $4.23 \pm 0.38$ \\
\hline Mann-Whitney U & 6919.000 & 6327.000 & 6601.000 & 7039.000 & 7640.000 & 6265.000 & 7068.500 \\
\hline p. & .225 & .029 & .065 & .308 & .975 & .022 & .333 \\
\hline
\end{tabular}


Tablo 4. Gebelerin GPSDÖ ve Alt Boyutları Lojistik Regresyon Analiz Sonuçları

\begin{tabular}{|c|c|c|c|c|c|}
\hline $\begin{array}{l}\text { Ölçüm } \\
\text { Düzeyleri }\end{array}$ & $\begin{array}{l}\text { İstatistiksel Olarak Anlamlı } \\
\text { Çıkan Bağımsız Değişkenler }\end{array}$ & $\beta$ & $\begin{array}{l}\text { Wald Test } \\
\text { İstatistiği }\end{array}$ & $e^{\beta}$ & $\mathbf{p}$ \\
\hline \multirow{5}{*}{ GPSDÖ } & Gebeliğin istenme durumu=Hayır & -1.136 & 5.187 & 0.321 & 0.023 \\
\hline & Gebeliğin istenme durumu=Evet & 0 & - & & - \\
\hline & Gelir durumu=Düşük & -2.912 & 5.100 & 0.054 & 0.024 \\
\hline & Gelir durumu=Orta & -2.006 & 2.952 & & 0.086 \\
\hline & Gelir durumu $=$ Yüksek & 0 & - & & - \\
\hline \multirow{8}{*}{$\begin{array}{l}\text { Aile içi } \\
\text { şiddete ait } \\
\text { özellikler }\end{array}$} & Eş eğitim durumu=İlkokul & -18.535 & 169.707 & $89 * 10^{8}$ & 0,000 \\
\hline & Eş eğitim durumu=Ortaokul & -21.259 & 251.413 & $6^{*} 10^{9}$ & 0.000 \\
\hline & Eş eğitim durumu=Lise & -19.354 & - & & - \\
\hline & Eş eğitim durumu=Üniversite & 0 & - & & - \\
\hline & Çekirdek aile & 2.964 & 9.470 & 19.375 & 0.002 \\
\hline & Geniş aile & 0 & - & & - \\
\hline & Gebelik takibi=Hayır & -5.136 & 14.023 & 0.005 & 0.000 \\
\hline & Gebelik takibi= Evet & 0 & - & & - \\
\hline \multirow{2}{*}{$\begin{array}{l}\text { Gebeliğe } \\
\text { ilişkin } \\
\text { fiziksel- } \\
\text { psikososyal } \\
\text { değisiikliklere } \\
\text { ait özellikler }\end{array}$} & Kürtaj $=$ Yok & 1.170 & 4.250 & 3.221 & $\mathbf{0 . 0 3 9}$ \\
\hline & Kürtaj=Var & 0 & - & & - \\
\hline
\end{tabular}

Gebelerin sosyo-demografik özelliklerine göre GPDSÖ Toplam ve Alt Boyutlarından aldıkları puanlar karşılaştırıldığında; gebelerin yaş grupları ile "Gebelik ve eş ilişkisi”, "Kaygı ve stres", "Psikososyal destek gereksinimleri" ve "Ailesel özellikler" alt boyut puanları arasında anlamlı fark saptanmıştır. Benzer şekilde Yılmaz ve Beji'nin (2010) yaptığ çalışmada

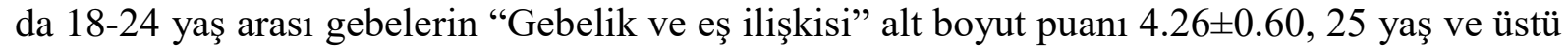
gebelerin $4.23 \pm 0.51$ olduğu bulunmuştur (10). Gebelerin yaşları arttıkça sorumlulukları da artmakta ve eşi ile ilişkisi olumsuz etkilenebilmektedir.

Gebelikte eş, aile ve/veya arkadaşlar tarafindan sağlanan psikososyal destek, gebeyi duygusal ve bilişsel olarak rahatlatmakta, sosyal kaynaklardan daha fazla yararlanmalarına, stres etkenleri ve kaygı ile daha kolay baş etmelerine yardımcı olmaktadır (6). Çalışmaya katılan gebeler eşleri ile ilişkilerinin iyi olduğu, psikososyal destek gereksinimlerinin yeterli karşılandığı ve ailesel özelliklerini iyi olarak tanımladığı belirlenmiştir. Araştırma bulguları Yıldız'ın (2011) çalışması ile benzerlik göstermektedir (7). Bu sonuçlar gebelerin aile bağlarının güçlü olduğunu, eş, eşinin ailesi ve/veya kendi ailelerinden yeterli düzeyde destek aldığının göstergesi olarak değerlendirilebilir.

Gebelik dönemi, kadınlar için doğal bir yaşam olayı olmanın yanı sıra önemli psikososyal değişimlerin yaşandığı kaygı ve stres oluşturabilecek birçok faktörle karşılaşma riskinin de yüksek olduğu bir evredir (9). Körükçü ve ark (2017) 226 gebe ile yaptı̆̆g çalışmada (11) ve bizim çalışmamızda gebelerin kaygı ve stres düzeyleri orta düzeyde bulmuştur. Literatürde de belirtildiği gibi gebelikte kaygı ve stres olağan görülmektedir.

Çalışmada gebelerin gebeliğe ilişkin fiziksel ve psikososyal değişiklikler bakımından iyi durumda oldukları belirlenmiş olup bulgular Yıldız'ın (2011) çalışması ile benzerdir (7). Bu 
durum gebelerin gebeliğe ilişkin fiziksel-psikososyal değişiklikleri gebeliğin bir parçası olarak kabullendiği ve geçici olduğunu düşündüklerini göstermektedir.

Çalışmamızda gebelerin yaşı arttıkça kaygı ve stresin azaldığı saptanmıştır. Kadının yaşı ilerledikçe gebelik ve doğum deneyimi ihtimali artmakta, kaygı ve stres düzeyleri hiç gebelik geçirmemiş kadınlara göre azalmaktadır. Çalışmamızla benzer olarak, Şahin ve Kılıçarslan'ın (2010) 340 gebe ile yaptığı çalışmada ise gebenin yaşı arttıkça kaygı düzeyinin azaldığ1 bulunmuştur (12). Bizim çalışmamızda yaşı 31 ve üzerinde olan gebelerin kaygı ve stres ile daha iyi baş edebildikleri belirlenmiştir.

Araştırmada gebelerin yaş gruplarına göre "Psikososyal destek gereksinimine ait özellikleri” ve "Ailesel özellikleri” alt boyut puanı ortalamaları incelendiğinde 25 yaş ve altı gebelerin puanlarının diğer yaş gruplarına göre iyi durumda olduğu bulunmuştur. Bu durum 25 yaş ve altında olan gebelerin ileri yaşta olan gebelere kıyasla evliliklerinin başlangıcında olmaları ve daha çok aile desteği almaları ile açıklanabilir.

Çalışmaya katılan gebelerin eğitim durumu ile GPDSÖ toplam puan ve "Gebelik ve eş ilişkisine ait özellikleri”, "Kaygı ve strese ait özellikler”, "Psikososyal destek gereksinimine ait özellikleri” ve "Ailesel özellikleri” alt boyut puanları arasında anlamlı fark saptanmıştır. Gebelerin eğitim durumu ile GPDSÖ toplam puan ve "Gebelik ve eş ilişkisine ait özellikleri”, "Kaygı ve strese ait özellikler", "Psikososyal destek gereksinimine ait özellikleri” ve "Ailesel özellikleri” alt boyut puanları incelendiğinde gebenin eğitim durumu arttıkça belirtilen alanlarda sağlık düzeyleri de artmıştır. Araştırmamızda gebelerin eğitim durumları arttıkça eş, aile ve sosyal çevre ile ilişkilerinin daha iyi olduğu ve doğum öncesi bakım, gerekli bilgi ve destek hizmetlerine daha kolay ulaşabildikleri söylenebilir.

Ayrıca araştırmada ilkokul mezunu gebelerin "Kaygı ve strese ait özellikler" alt boyut puanın yüksek olduğu belirlenmiştir. İlkokul mezunu gebelerin kaygı ve strese yönelik sağlık düzeylerinin diğer gebelerden iyi olması bu gebelerin kaygı ve stres algılarının farklılı̆̆ından kaynaklanmış olabilir.

Araştırmada çalışan gebelerin "Gebelik ve eş ilişkilerine ait özellikleri” ve toplam "GPDSÖ” puanlarının daha yüksek olduğu ve sağlık düzeylerinin iyi olduğu saptanmıştır. Yapılan çalışmalarda gebelerin çalışma yaşamında yer almaları öz bakımlarının (10), benlik saygılarının daha yüksek olduğu (13) bildirilmektedir. Bödecs ve ark. (2013) Macaristan’da 503 gebe ile yaptıkları çalışmada işsiz olan gebelerin depresyon ve anksiyete puanlarının daha yüksek olduğu bulunmuştur (14). Bizim çalışmamız ve yapılan çalışmalarda gebelerin çalışma yaşamında yer almaları sağlık durumlarını olumlu etkilemiştir. Gebelerin gelir durumuna göre "Gebelik ve eş ilişkilerine ait özellikleri”, "Psikososyal destek gereksinimine ait özellikleri”, “Ailesel özellikleri” alt boyut ve GPDSÖ toplam puanı ortalaması incelendiğinde gelir durumu yüksek olan gebelerin puanlarının daha yüksek olduğu tespit edilmiştir.

Gebelerin eşlerinin sosyo-demografik özelliklerine göre GPDSÖ Toplam ve alt boyutlarından aldıkları puanlar karşılaştırıldığında; gebelerin eşlerinin yaş grupları ile "Gebelik ve eş ilişkisine ait özellikler” ve "Ailesel özellikler" alt boyut incelendiğinde 25 yaş ve altında olan grubun puanlarının yüksek olduğu belirlenmiştir. Bu durumun araştırmaya katılan gebelerin eşlerinin yaşı arttıkça sorumluluklarının da artması sebebiyle eşi ile ilişkisinin ve aile ilişkilerinin değişmesinden bağlı kaynaklandığı düşünülmektedir.

Araştırmaya katılan gebelerin eşlerinin eğitim durumu ile "Gebelik ve eş ilişkisine ait özellikler”, "Kaygı ve strese ait özellikler”, “Aile içi şiddete ait özellikler”, "Psikososyal destek 
gereksinimine ait özellikler" ve "Ailesel özellikler" alt boyut puan ortalamaları ile GPDSÖ toplam puanı incelendiğinde eşin eğitim durumu arttıkça gebenin psikososyal sağlık düzeyinin de arttığı belirlenmiştir. Bu durum gebenin eşinin eğitim durumunun yüksek seviyede olması gebelik hakkında daha fazla bilgi edinmesine ve eşine daha iyi destek olmasını ile açıklanabilir.

Gebelerin obsterik özelliklerine göre GPDSÖ Toplam ve alt boyutlarından aldıkları puanlar karşılaştırıldığında araştırmaya katılan gebelerin gebelik sayısı, canlı doğum sayısı ve yaşayan çocuk sayısı ile "Gebelik ve eş ilişkisine ait özellikler", "Psikososyal destek gereksinimine ait özellikler" ve "Ailesel özellikler” alt boyut puanı incelendiğinde, ilk gebeliği olan ve yaşayan çocuğu olmayanların puan ortalamaları, birden fazla gebelik yaşayan, canlı doğum yapmış ve yaşayan çocuğu olanlara göre daha yüksek olduğu tespit edilmiştir. Gebelik sayısı arttıkça yaşayan çocuk sayısının ve sorumlulukların da artmasına sebep olabilir. $\mathrm{Bu}$ durumun araştırmaya katılan gebelerin eşi ve ailesiyle ilişkilerini ve psikososyal sağlığını etkilediği düşünülmektedir.

Araştırmaya katılan gebelerin gebelik sayısı, canlı doğum sayısı ve yaşayan çocuk sayısı ile "Kaygı ve strese ait özellikler" alt boyut puanı ortalaması incelendiğinde, birden fazla gebelik yaşayan, canlı doğum yapmış ve yaşayan çocuğu olan gebelerin puan ortalamaları, ilk gebeliği olan ve yaşayan çocuğu olmayanlara göre daha yüksek olduğu bulunmuştur. Üst ve Pasinlioğlu'nun (2015) primipar ve multipar gebelerde doğum ve doğum sonu döneme ilişkin endişelerini inceledikleri çalışmalarında primiparlar gebelerin endişe düzeylerinin multiparlardan daha yüksek olduğu saptanmıştır (15). Körükçü ve ark. (2017) çalışmalarında ise primipar gebelerin yaşadıkları doğum korkusu seviyesinin daha yüksek olduğu belirtilmiştir (11). Araştırmamıza katılan, ilk gebeliği olan, daha önce canlı doğum yapmamış ve yaşayan çocuğu olmayan gebelerin deneyimsiz oldukları için doğum anında ve doğumdan sonra karşılaşabilecekleri olayları tahmin edememekte, bu durum onların kaygı ve streslerini arttırabilmektedir.

Araştırmaya katılan gebelerin gebeliğin planlama ve gebeliğin istenme durumu ile GPDSÖ toplam puan, "Gebelik ve eş ilişkisine ait özellikler”, "Aile iç şiddete ait özellikler”, "Psikososyal destek gereksinimine ait özellikler", ve "Ailesel özellikler" alt boyut puan ortalamasına bakıldığı zaman gebeliği planlayan ve isteyen gebelerin psikososyal sağlık düzeyleri daha iyi durumdadır. Bizim çalışmamızda gebelerin yarısından fazlasının gebeliğini planladığı ve istediği belirlenmiştir. Gebeliğin istenen ve planlanmış gebelik olması eşin desteğinin arttırdığı, ayrıca doğacak bebek hakkında gebenin ve eşinin planlar yapmasını sağladığı ve gebenin kendini anne olmaya daha hazır hissettiği saptanmıştır.

Gebelerin gebelik risk durumuna göre GPDSÖ toplam ve alt boyutlarından aldıkları puanlar karşılaştırıldığında; gebelerin risk durumu ile "Gebelik ve eş ilişkisine ait özellikler" alt boyut puanı incelendiğinde gebeliğinde riski olmayanların puanının olumlu yönde arttı̆̆ tespit edilmiştir.

Gebelerin risk durumu ile "Kaygı ve strese ait özellikler" alt boyut puanı ortalamasına bakıldığında gebeliği riskli olanların puan ortalamasının daha yüksek olduğu bulunmuştur. Çalışmanın merkezde yapılmış olması ve çalışmaya katılan riskli gebelerin doğum öncesi bakım, gerekli bilgi ve sağlık hizmetlerine kolay ulaşabilmelerinden kaynaklanabilir. Araştırmaya katılan gebelerin mevcut gebeliğinde risk durumu ile "Kaygı ve strese ait özellikler" ve "Gebeliğe ilişkin fiziksel-psikososyal değişikliklere ait özellikler" alt boyut puanları ile incelendiğinde mevcut gebeliği riskli olanların puan ortalamasının olumu yönde 
arttığı belirlenmiştir. Bizim çalışmamıza katılan gebelerin çoğunluğunun gebeliğini istemiş ve planlamış olması, fiziksel-psikososyal değişiklikleri olağan görmesi riskli gebelerin psikososyal sağlik durumunu olumlu etkilemiştir.

Yapılan lojistik regresyon analizi sonucuna göre gebeliğini isteyenlerin, gebeliğini istemeyenlere göre psikososyal sağlık düzeyleri 0.321 kat daha fazladır. Araştırmaya katılan gelir durumu yüksek olan gebelerin, düşük olan gebelere göre "Gebelik ve eş ilişkisine ait özellikler" alt boyut puanı 0.054 kat daha fazladır. Çalışmamıza katılan gebelerin gelir durumu arttıkça kendilerini daha güvende hissettikleri, daha az gelecek kaygısı yaşadıkları, gebe ve eş arasındaki ilişkiyi olumlu etkilediği düşünülmektedir.

Çekirdek ailede yaşayan gebelerin, geniş ailede yaşayan gebelere göre "Aile iç şiddete ait özellikler" alt boyut puanı 19.375 kat daha yüksektir. Yapılan çalışma sonuçları da bizim çalışmamızın bulgularına benzer olarak, geniş ailede yaşayan gebelerin aile içi şiddete maruz kalma riskinin daha fazla olduğunu göstermektedir $(18,19)$.

Gebelerin eşlerinin eğitim durumu ilkokul ve ortaokul olanların "Aile iç şiddete ait özellikler" alt boyut puanı, eşinin eğitim durumu üniversite olan bireylere göre istatistiksel olarak daha düşük olduğu görülmektedir. Yapılan araştırmalarda eğitim durumunun düşük olmasının aile içi şiddetle ilişkili faktörlerden olduğu tespit edilmiştir. Gebelikte aile içi şiddetin tüm toplumlarda sıklıkla yaşanmasına rağmen sağlık profesyonelleri tarafından nadiren ele alınmaktadır. Ebelerin, doğum öncesi izlemde, gebelikte aile içi şiddete uğrayan kadınları belirlemek ve yardımcı olmak için önemli bir göreve sahiptir $(17,20)$.

Doğum öncesi izleme gitmeyen gebelerin, izleme giden gebelere göre "Aile iç şiddete ait özellikler" alt boyut puanı 0,005 kat daha düşüktür. Güler (2010)'in 403 gebe ile yaptığ çalışmada doğum öncesi izleme gitmeme durumunun şiddeti arttıran risk etmenleri arasında olduğu gösterilmektedir (17).

Araştırmada daha önce kürtajı olmayan gebelerin, kürtajı olan gebelere göre "Gebeliğe ilişkin fiziksel-psikososyal değişikliklere ait özellikler” alt boyut puanı 3.221 kat daha yüksek bulunmuştur. Gebelerin daha önce geçirilmiş kürtaj varlığı onların gebelikte fiziksel-psikolojik değişiklikleri kabullenmede olumsuz etki yaratmıştır.

\section{SONUÇ VE ÖNERİLER}

Sonuç olarak araştırmaya katılan gebelerin psikososyal sağlık düzeylerinin iyi olduğu sonucuna varılmıştır. Gebelerin genel olarak psikososyal sağlık düzeylerini gebeliği isteme durumu olumlu yönde etkilemiştir. Yüksek gelir düzeyi olan gebelerin gebelik ve eş ilişkileri daha olumlu bulunmuştur. Çekirdek ailede yaşayan ve gebelik takibi yaptırmayan gebelerin ise aile içi şiddete ait özellikler bakımından olumsuz etkilendiği saptanmıştır. Ayrıca daha önce kürtaj olmayan gebelerin gebeliğe ilişkin psikososyal değişiklikleri daha olumlu karşıladığ tespit edilmiştir. Gebelikte risk durumu psikososyal sağlı̆̆ etkilemediği saptanmıştır.

Doğum öncesi izlemlerde gebelerin mutlaka psikososyal sağlık açısından da değerlendirilmesi ve gerekli önlemlerin alınması doğum öncesi bakımın niteliğini arttıracağını düşünmekteyiz. 


\section{Araştırmanın Etik Yönü}

Araştırma için 12.05.2016 tarihinde Adnan Menderes Üniversitesi Tıp Fakültesi Girişimsel Olmayan Klinik Araştırmalar Etik Kurulundan (Protokol no:2016/862) ve Aydın Halk Sağlık Müdürlüğü'nden yazılı izin alınmıştır. Araştırmaya katılan gebelere araştırma hakkında bilgi verildikten sonra sözlü ve yazılı onamları alınmıştır.

\section{Çıkar Çatışması}

Yazarlar arasında çıkar çatışması yoktur.

\section{Teşekkür}

$\mathrm{Bu}$ araştırmaya katılan kadınlara teşekkür ederiz.

\section{KAYNAKLAR}

1. Çalık, K. Y., Aktaş, S. (2011). Gebelikte depresyon: sıklık, risk faktörleri ve tedavisi. Güncel Yaklaşımlar, 3, 142-162.

2. Daştan, N., Deniz, N., \& Şahin, B. (2015). Kars’ta gebelerin ev ziyareti ile ruhsal durumlarının belirlenmesi. Psikiyatri Hemşireliği Dergisi, 6(2), 71-78.

3. Koyuncu, S. B., Y1lmaz, S. M. (2015). Son trimester nullipar gebelerde bazı sosyodemografik ve obstetrik özelliklerin psikososyal sağlık düzeyine etkisi. Ege Üniversitesi Hemşirelik Fakültesi Dergisi, 31(2), 53-66.

4. Karaçam, Z., Ançel, G. (2009). Depression, anxiety and influencing factors in pregnanacy:a study in a Turkish population. Midwifery, 25(4), 344-356.

5. Çapık, A., Apay, S., \& Sakar, T. (2015). Gebelerde distres düzeyinin belirlenmesi. Anadolu Hemşirelik ve Sağllk Bilimleri Dergisi, 18(3), 196-203.

6. Vırıt, O., Akbaş, E., Savaş, H. A., Sertbaş, G., \& Kandemir, H. (2008). Gebelikte depresyon ve kaygı düzeylerinin sosyal destek ile ilişkisi. Nöropsikiyatri Arşivi, 45(1), 9-13.

7. Yıldız, H. (2011). Gebelerde psikososyal sağlığı değerlendirme ölçeği geliştirme çalışması. Maltepe Üniversitesi Hemşirelik Bilim ve Sanat Dergisi, 4, 63-74.

8. T.C. Sağlık Bakanlığı. Doğum Öncesi Bakım Yönetim Rehberi. https://khgmsaglikhizmetleridb.saglik.gov.tr/Eklenti/28085/0/dogumoncesibakimyone timrehberipdf.pdf (Erişim Tarihi: 24 Şubat 2016).

9. Gümüşdaş, M., Apay, S., \& Özorhan, E. Y. (2014). Riskli olan ve olmayan gebelerin psikososyal sağlıklarının karşılaştırılması. HSP, l(2), 32-42.

10. Yılmaz, S. D., Beji, N. K. (2010). Gebelikte öz bakım gücünün değerlendirilmesi. Genel Tip Dergisi, 20(4), 137-142.

11. Körükçü, Ö., Deliktaş, A., Aydın, R., \& Kabukcuoğlu, K. (2017). Gebelikteki psikososyal sağlık durumu ile doğum korkusu arasındaki ilişkinin incelenmesi. Clinical and Experimental Health Sciences, 7, 152-158.

12. Şahin, E. M., Kılıçarslan, S. (2010). Son trimester gebelerin depresyon ve kayg1 düzeyleri ile bunları etkileyen etmenler. Trakya Üniversitesi Tip Fakültesi Dergisi, 27(1), 51-58. 
13. Arslan, B., Arslan, A., Kara, S., Öngel, K., \& Mungan, M. T. (2011). Gebelik anksiyete ve depresyonunda risk faktörleri:452 olguda değerlendirme. Tepecik Ĕ̈itim Hastanesi Dergisi, 21(2), 79-84.

14. Bödecs, T., Szilagyi, E., Cholnoky, P., Sandor, J., Gonda, X., Rihmer, Z., et al. (2013). Prevalence and psychosocial background of anxiety and depression emerging during the first trimester of pregnancy: Data from a hungarian population-based sample. Psychiatria Danubina, 25(4), 352-358.

15. Üst, D. Z., Pasinlioğlu, T. (2015). Primipar ve multipar gebelerde doğum ve doğum sonu döneme ilişkin endişelerin belirlenmesi. HSP, 2(3), 306-317.

16. Demirbaş, H., Kadığlu, H. (2014). Prenatal dönemdeki kadınların gebeliğe uyumu ve ilişkili faktörler. Marmara Üniversitesi Sağlık Bilimleri Enstitüsü Dergisi, 4(4), 200206.

17. Güler, N. (2010). Gebelikte eşi tarafından kadına uygulanan fiziksel, duygusal, cinsel ve ekonomik şiddet ve ilişkili faktörler. Dokuz Eylül Üniversitesi Hemşirelik Yüksekokulu Elektronik Dergisi, 3(2), 72-77.

18. Bozkurt, D. Ö., Daşıkan, Z. (2016). Gebelikte eş şiddeti: Risk faktörleri, sağlık sonuçları ve tarama araçları. Türkiye Klinikleri Journals Obstetric Womens Health and Diseases Nursing-Special Topics, 2(2), 15-22.

19. Şahin, S., İlçıoğlu, K., \& Ünsal, A. (2017). Domestic violence, depression and anxiety during pregnancy. Hemşirelikte Eğitim ve Araştırma Dergisi, 14(3), 204-211.

20. Sağkal, T., Kalkım, A., Uğurlu, E. S., \& Kırmızılar, N. E. (2014). Gebelerin eşi tarafından şiddete maruz kalma durumları ve şiddetle ilişkili faktörlerin incelenmesi. TAF Preventine Medicine Bulletin, 13(5), 381-390. 